УДК: 94 (477)“'2014”

DOI: $10.33099 / 2707-1383-2021-41-3-87-97$

\title{
Микола Кравченко
}

кандидат історичних наук, докторант

Інститут украӥнської археографії та джерелознавства ім. М. С. Грушевського НАН України (Київ, Україна) ORCID: https://orcid.org/0000-0003-1908-1595 Електронна пошта: 2005kms83@gmail.com

\section{ОСОБЛИВОСТІ СТРУКТУРНОЇ ПОБУДОВИ ДОБРОВОЛЬЧОГО БАТАЛЬЙОНУ «АЗОВ» У ТРАВНІ-ВЕРЕСНI 2014 РОКУ ЗА МАТЕРІАЛАМИ АРХІВУ НЕРЕГЛАМЕНТОВАНОЇ БАТАЛЬЙОННОЇ ДОКУМЕНТАЦЇ̈}

\begin{abstract}
В статті досліджено прочеси становлення внутрішньої структури добровольчого батальйону «Азов», відображені у внутрішній нерегламентованій документачії підрозділу. Оглянуто особливості иієї структурної побудови, а також формування підрозділів, щьо складали батальйон. Дослідження проведене на основі матеріалів збірки нерегламентованої батальйонної документаџії, яка у 2020 роиі була зафондована Центральним державним архівом громадських об'єднань України. Зроблено висновки щзодо взаємозв'язку внутрішньої структурної побудови добровольчого батальйону та бойової ефективності підрозділу впродовж травня-вересня 2014 року.
\end{abstract}

Ключові слова: добровольчий рух, українські добробати, нерегламентована документачія, Антитерористична операџія, батальйон «Азов».

Постановка проблеми. Внесок українських добровольчих формувань в перебіг Антитерористичної операції (далі - АТО) на Сході України у 2014-2015 роках не варто оцінювати за середнім показником. Український добровольчий рух зазначеного періоду був надзвичайно неоднорідним і діяльність окремих його учасників (маються на увазі добро- вольчі формування, а не окремі добровольці) була настільки різною за масштабом і значенням, що усереднювати іiі щонайменше некоректно. Внесок одних добробатів без сумніву непересічний, внесок ряду інших на порядок скромніший. Діяльність і особливості тих добровольчих підрозділів, що зробили значний внесок у перебіг АТО (особливо на початко- 
вому іiі етапі) без сумніву заслуговує на окремі дослідження. Це не тільки сприятиме узагальненню бойового досвіду із захисту територіальної цілісності країни і національно-патріотичному вихованню громадян, але й дасть можливість детальніше вивчити причинно-наслідкові зв'язки між окремими епізодами й етапами військово-політичної історії України досліджуваного періоду.

Аналіз останніх досліджень. Серед таких добровольчих підрозділів, історію яких варто досліджувати окремо, особливе місце посідає батальйон «Азов». Він відіграв ключову роль у військовій операції з визволення Маріуполя (Гладка, К., Громаков, Д. \& Миронова, В. (упоряд.) та ін. 2017, с. 163-165; Кравченко, М. (упоряд.). 2018, с. 3), яка стала одним 3 поворотних моментів у перебігу військових дій на Донбасі. Відновлення української влади у цьому потужному місті-порті унеможливило утворення контрольованого російсько-терористичними силами суходільного коридору між тимчасово окупованими «материковими» територіями та анексованим Кримським півостровом. А відсутність такого коридору багато в чому зумовила неможливість подальшого розширення контрольованих проросійськими сепаратистами територій на Півдні України, а отже й багато в чому зумовило весь подальший перебіг бойових дій. Окрім визволення Маріуполя добровольці-азовці відіграли також значну роль і в стратегічно важливій обороні Приазов'я на початку вересня 2014 року (Гладка, К., Громаков, Д. \& Миронова, В. (упоряд.) та ін. 2017, с. 222-225), завдяки чому статус Маріуполя не змінився i місто не потрапило ні під контроль проросійських сил, ні в «сіру зону».

Суттєве значення для бойової ефективності «Азову» мала його внутрішня структурна побудова, яка багато в чому зумовлювала ефективне управління підрозділом і функціонування окремих його складових. Український добровольчий рух загалом був предметом дослідження як окремих науковців (Бутусов, Ю. 2014; Гуральська, А. 2015; Стасюк, Ю. М. 2018) так і колективних робіт (Гладка, К., Громаков, Д. \& Миронова, В. (упоряд.) та ін. 2017), а от комплексного дослідження батальйону «Азов» як окремого добровольчого феномену, а тим більше його внутрішньої структурної побудови, в межах академічної науки до сьогодні не здійснювалося. Саме ця недослідженість і зумовлює актуальність даної розвідки.

Дана стаття готувалася 3 використанням виключно відкритих джерел i не містить жодних даних, що становлять державну таємницю чи мають обмежений доступ.

Дослідити внутрішню структурну побудову «Азову» i визначити іiі особливості наразі можна лише використовуючи матеріали архіву внутрішньої нерегламентованої доку- 
ментації батальйону (далі - Архів), адже інших документів, які комплексно відображають досліджувану проблематику наразі просто немає. Восени 2020 року нерегламентована батальйонна документація «Азову» була зафондована Центральним Державним архівом громадських об’єднань (далі - ЦДАГО) в межах новоутвореного фонду 361 «Колекція документів 3 проведення Антитерористичної операції на тимчасово окупованих територіях України та діяльності волонтерського руху в Україні» ${ }^{1}$. Архів $\epsilon$ результатом роботи 3 упорядкування нерегламентованої документації ветеранською спільнотою азовських добровольців (“Азов”. 2020). Передача зазначених документів до ЦДАГО України не погоджувалася з ані з Міністерством внутрішніх справ, ані з командуванням Національної Гвардії України (у підпорядкуванні якої наразі перебуває підрозділ-спадкоємець однойменного батальйону — окремий загін спеціального призначення «Азов»), адже ведення даної документації не регламентовано державними приписами і являє собою власну ініціативу добровольців, які наразі $€$ ветеранською спільнотою.

Той факт, що зміст і формат зафондованої ЦДАГО документації не обмежують жодні регламентовані ззов-

1 ЦДАГО України. Ф. 361. Оп. 1. Спр. 1-8. «Навчально-мобілізаційний центр “Козацький Легіон”». Добровольчий батальйон «Азов». ні чинники, надає цим документам особливо важливого значення для дослідження, адже події в них фіксуються у такому вигляді, якими вони справді були (чи принаймні здавалися їх авторам) на момент їх фіксації. Дані джерела містять не затребувані вищим командуванням та типовими нормативними документами відомості, а ті дані, які потребували фіксації на думку самих авторів, які перебували всередині процесу діяльності добровольчого батальйону. Саме це й зумовлює особливу цінність таких джерел. Адже завдяки цим документам маємо можливість досліджувати внутрішні процеси батальйону з точки зору добровольців-функціонерів підрозділу, які формували внутрішню батальйонну документацію.

Формулювання мети. Метою даної розвідки $є$ визначення внутрішньої структурної побудови батальйону «Азов», процесу іiі формування, корекції та особливостей. Для досягнення даної мети необхідно виконати наступні завдання:

- здійснити огляд матеріалів архіву нерегламентованої документації батальйону «Азов», що висвітлюють особливості внутрішньої структурної побудови підрозділу;

- проаналізувати особливості висвітленої зазначеними документами структурної побудови і на підставі цього зробити висновки щодо впливу даних особливостей на бойову ефективність підрозділу. 


\section{Виклад основного матеріалу.} 3і змісту документів батальйонного навчально-мобілізаційного центру «Козацький легіон»², які складають близько третини всього Архіву, можна стверджувати, що колектив, який склав організаційну основу «Азова» був сформований ще до утворення батальйону і на момент започаткування підрозділу вже мав певну внутрішню структуру. До середини червня ця структура, зважаючи на оновлений формат діяльності, зазнавала постійних змін, зумовлених передусім перманентним наповненням підрозділу новими добровольцями. Певне устійнення в цьому процесі фіксує внутрішній батальйонний наказ № 02/14³, який власне закріплює структуру батальйону. До цього моменту батальйон являв собою по суті поєднання двох складових:

- навчально-мобілізаційного центру «Козацький легіон», який дислокувався у Києві та відігравав роль набірної комісії, прес-центру, тренувальної і тилової бази одночасно;

- фронтової структури, поділеної на десятки (аналоги армійських відділень) й чоти (аналоги армійських взводів), яка перебувала в зоні АТО і здійснювала безпосереднє виконання бойових завдань.

\footnotetext{
2 ЦЛАГО України. Ф. 361. ОП. 1. Спр. 1-3. «Навчально-мобілізаційний центр “Козацький Легіон”».

3 ЦДАГО України. Ф. 361. Оп. 1. Спр. 4. «Накази по батальйону». Арк. 2.
}

Періодично 3 «Козацького легіону» вирушали в напрямку зони АТО поповнення (в Архіві до них застосовується термін «похідні групи»), які тимчасово являли собою третій елемент батальйонної побудови, який вже перестав бути частиною «Козацького легіону», але ще не став підрозділом фронтової структури. Втім, існували «похідні групи» вочевидь не більше доби-двох — часу, за який вони прибували 3 Києва до Бердянська (первісного місця дислокації «Азова» в безпосередній близькості до зони АТО) чи Урзуфа (головного місця дислокації фронтової частини батальйону впродовж літа-осені 2014 року) і вливалися до складу фронтових структур.

Уже з самих назв і форматів структурних підрозділів батальйону стає зрозуміло, що його внутрішня побудова суттєво дисонувала 3 приписами, регламентованими документами Міністерства внутрішніх справ (далі - MBC) і має похідний характер від націоналістичних громадських організацій, на базі яких був сформований партизанський загін «чорних чоловічків» (первісного колективу, з якого згодом постала кадрова основа «Азову»). Міліцейські батальйони, як правило, не мали власних прес-центрів, тилових чи тренувальних баз, використовуючи для цього спеціалізовані структурні підрозділи у складі органів МВС. Завдяки ж наявності власних «позафронтових» ресурсів «Азов» активно діяв 
не тільки на передовій, але і в інформаційному просторі, що має важливе значення в умовах, коли військові діï $є$ гібридними і являють собою не тільки безпосередньо фронтове протиборство, але і протистояння в інформаційній площині. У спогадах добровольців «Азову» неодноразово згадується, що інформаційна складова мала безпосередній вплив i на перебіг подій на фронті, адже чутки нерідко призводили до паніки в рядах противника. Так, гіпертрофоване уявлення про жорстокість «чорних чоловічків» (українських партизанів, які склали основу «Азова» на першому етапі формування) кілька разів спричиняло до ухилення сепаратистів від безпосереднього зіткнення. Витік інформації про майбутній штурм Маріуполя призвів до того, що частина проросійських бойовиків в ніч на 13 червня 2014 року (напередодні визволення) просто втекла 3 міста. Цей епізод неодноразово згадується у спогадах учасників операції (Кравченко, М. (упоряд.). 2018).

Як вже було зазначено вище, устійнення батальйонної структури відбулося внутрішнім наказом по батальйону № 02/14 ${ }^{4}$, який датовано 13 червня 2014 року. Ця дата — день визволення Маріуполя i вочевидь саме за результатами даної військової операції було прийнято рішення про переформатування структури

4 ЦДАГО України. Ф. 361. Оп. 1. Спр. 4. «Накази по батальйону». Арк. 2. підрозділу. Отже з середини червня 2014 року батальйон складався 3 наступних лінійних i функціональних підрозділів ${ }^{5}$ :

- штаб на чолі 3 «Галайдою» (в подальших документах Архіву всі безпосередньо підпорядковані батальйонному штабу структури об'єднуються терміном «штабна сотня»);

- 1 сотня на чолі 3 «Черкасом»;

- 2 сотня на чолі 3 «Гуманістом»;

- 3 сотня на чолі 3 «Палієм»;

- окрема ударно-штурмова чота на чолі 3 «Галом»;

- окрема розвідувально-диверсійна чота на чолі 3 «Боцманом».

Всі три лінійні сотні (аналоги армійських рот) мали внутрішній поділ на чоти (взводи), які в свою чергу поділяються на десятки (відділення).

Тим же внутрішнім наказом 6 , регламентується творення наступних підрозділів у безпосередньому підпорядкуванні батальйонного штабу:

- група кадрового забезпечення на чолі 3 «Круком»;

- медична служба на чолі з «Доктором Хаусом»;

- радіо-технічна служба на чолі 3 «Кваснєвським» (8 серпня 2014 року на цій посаді він був замінений на « $\left(70-\right.$-го» $\left.{ }^{7}\right)$;

- обозна (тилова) служба на чолі 3 «Алексом»;

5 Ibid.

6 Ibid.

7 ЦДАГО України. Ф. 361. Оп. 1. Спр. 4. «Накази по батальйону». Арк. 4. 
- авточота (транспортний взвод) на чолі 3 «Бугром»;

- оперативний відділ на чолі 3 «Душманом».

3 липня 2014 року у документах Архіву батальйонний навчально-мобілізаційний центр «Козацький легіон» починає фігурувати під назвою «вишкільна сотня» ${ }^{8}$. Того ж місяця в документах Архіву фіксується і ускладнення структури батальйонного штабу 9 . У штабному підпорядкуванні 3'являються група охорони, група розвідки, конвой, зброярня та політичний відділ (який вже через місяць, у серпні, обліковується як кореспондентський центр ${ }^{10}$ ). А вже у вересні у документах Архіву 3'являється ще один новий підрозділ - вартова чота. 3 огляду на те, що позивні добровольців, які ії складали зустрічаються вперше у документах, датованих вереснем 2014 року, то варто припустити, що дана чота сформована новою «похідною групою» 3 «Козацького легіону» ${ }^{11}$.

16 серпня 2014 року процесі участі в Іловайській операції за участю представників всіх функціональних служб штабу в польових умовах був розгорнутий Центр Бойового Управ-

8 ЦДАГО України. Ф. 361. Оп. 1. Спр. 6. «Списки особового складу, бійців батальйону, добровольців, втрат батальйону, поранених бійців, повернення 3 ротацій тощо». Арк. 1.

9 Ibid. Арк. 3.

${ }^{10}$ Ibid. Арк. 5.

${ }^{11}$ Ibid. Арк. 25. ління (ЦБУ) $)^{12}$. Такий формат функціонування штабних структур в українських армійських підрозділах та інших добровольчих батальйонах впродовж 2014 році більше ніде не фіксується. Втім, наявність структур, схожих за функціоналом до ЦБУ «Азова», наявний у військових підрозділів країн НАТО. Отже, утворенням ЦБУ в «Азові» батальйонне командування вочевидь намагалися локально застосовувати військовий досвід армій НАТО. Даний досвід вочевидь був переданий командуванню батальйону іноземними добровольцями з західних країн, які на той момент перебували у складі підрозділу.

Впродовж серпня 2014 року (вочевидь також в процесі участі батальйону в Іловайській операціï) специфічної структури (порівняно 3 іншими батальйонними лінійними підрозділами) набула розвідувально-диверсійна чота. Станом на 31 серпня 2014 року фіксується наступна структура даної чоти ${ }^{13}$ :

- командна ланка (у складі командира, бійця і медика);

- 2 лінійні десятки (один 3 яких спеціалізується на власне розвідці);

- 3 окремі ланки вогневої підтримки (озброєні відповідно станковим

${ }^{12}$ ЦДАГО України. Ф. 361. Оп. 1. Спр. 4. «Накази по батальйону». Арк. 18.

${ }^{13}$ ЦДАГО України. Ф. 361. Оп. 1. Спр. 6. «Списки особового складу, бійців батальйону, добровольців, втрат батальйону, поранених бійців, повернення 3 ротацій тощо». Арк. 16. 
автоматичним гранатометом, ручним протитанковим гранатометом, великокаліберним кулеметом «Утьос»);

- окрема снайперська група (у складі 2х снайперських пар);

- чотовий обоз.

3 назв підрозділів зрозуміло, що всі вони мали окрему специфіку роботи, яка зумовлювалася розвідувально-диверсійним характером роботи чоти в цілому.

Наприкінці серпня 2014 року, коли 3 напрямку Новоазовська на Маріуполь розпочався наступ російсько-терористичних військ і місто активно готувалося до оборони, у складі батальйону «Азов» відбулися чергові структурні зміни, точніше доповнення. Внутрішніми наказами №№ 2829/14 ${ }^{14}$ від 25 та 31 серпня 2014 року відповідно у підпорядкування штабу батальйону були прийняті новостворені 1-ша та 2-га резервні чоти. Ці допоміжні підрозділи були сформовані 3 маріупольських добровольців та членів громадської організації «Маріупольська дружина», які зголосилися долучитися до добробату через загрозу російського штурму їх рідного міста, який очікували найближчими днями. Таке розширення штату було тимчасовим і вимушеним. Дані резервні чоти не були ані навченими, ані злагодженими, їх планувалися залучати для виконання задач виключно у разі штурму міста

14 ЦДАГО України. Ф. 361. Оп. 1. Спр. 4. «Накази по батальйону». Арк. 28-29. ворожими військами. В джерелах не відображена подальша доля даних резервних формувань, але наявні згадки про участь цивільних добровольців в побудові фортифікаційних споруд на підступах до міста (Гладка, К., Громаков, Д. \& Миронова, В. (упоряд.) та ін. 2017, с. 215). Тож, $\epsilon$ вірогідність, що маріупольські резервні чоти «Азова» використовувалися саме на цих роботах, адже дані фортифікаційні споруди протягом наступних кількох діб утримувалися саме добровольцями «Азова» (Гладка, К., Громаков, Д. \& Миронова, В. (упоряд.) та ін. 2017, с. 220). Втім, таке твердження все ж не є однозначним. Найімовірніше, що 4-5 вересня 2014 року, після успішного закінчення оборони Маріуполя, потреба в резервних чотах відпала і особовий склад, що їх складав, або розійшовся по домівках або ці добровольці долучилися до батальйону «Азов», але вже у персональному порядку.

Останнім документом Архіву, що прямо регламентує структурні зміни в батальйоні, є внутрішній наказ № 32/14 $4^{15}$, датований 13 вересня 2014 року. Цим документом у складі «Азову» була створена танкова чота (взвод) під командуванням «Душмана». Втім, у вересні 2014 року підрозділ був створений лише на папері. Наказ доручав «Душману» набір особового складу майбутньої

15 ЦДАГО України. Ф. 361. Оп. 1. Спр. 4. «Накази по батальйону». Арк. 32. 
чоти та організацію його навчання. Азовські танки 3'явилися на передовій аж у березні наступного, 2015, року (Хомеріккі, М. (упоряд.). 2016, с. 16-17). Тож, час 3 вересня 2014 року до березня 2015 року не було змарновано - підбір особового складу і його підготовка відбулися у відносно короткий термін. Але танковий підрозділ функціонував вже не у складі батальйону «Азов». У вересні 2014 року підрозділ був розширений до однойменного полку, а в листопаді-грудні того ж року перейшов до складу Національної Гвардії України як окремий загін спеціального призначення «Азов».

Подальші плани на кількісне i структурне розширення підрозділу яскраво ілюструє документ Архіву, що носить назву «Пропозиції по розширенню структури батальйону “Азов"»" ${ }^{16}$. Ці пропозиції свідчать, що батальйон планував подальше розширення до складу не полку, а одразу бригади 3 суттєвим збільшенням штатів та функціоналу. Але цікавий цей документ передусім тим, що містить порівняння формальної і реальної структурної побудови батальйону, що прямо підтверджує суттєве розходження між документарним i фактичним станом справ. Головна відмінність між

\footnotetext{
16 ЦДАГО України. Ф. 361. Оп. 1. Спр. 6. «Списки особового складу, бійців батальйону, добровольців, втрат батальйону, поранених бійців, повернення 3 ротацій тощо». Арк. 26.
}

структурами де-юре і де-факто - це спеціалізація підрозділів батальйону. Ударно-штурмових і тим більше розвідувально-диверсійних підрозділів у штатній структурі батальйону патрульної служби міліції (яким формально вважався «Азов» в системі $\mathrm{MBC)} \mathrm{не} \mathrm{передбачалося} \mathrm{в} \mathrm{принци-}$ пі. Приписи МВС не передбачають i наявності окремого батальйонного штабу, а тим більше таких специфічних підрозділів як оперативний і політичний відділи. Не передбачено в патрульній міліції і групи розвідки, повністю відсутня радіо-технічна служба. А новоутворена (хоч і лише документарно) у вересні 2014 року танкова чота у міліцейського батальйону існувати не може за визначенням. Все це зумовлено тим, що документообіг та й саме функціонування органів внутрішніх справ не були розраховані на ведення його підрозділами безпосередньо бойових дій. Таким чином документарні матеріали, що наразі зберігається в архівах MBC і доступ до яких сьогодні охороняється грифами секретності, вочевидь не відображає реального стану речей. Отже, використання подібних документів для дослідження історії добровольчого руху потребуватиме суттєвої верифікації.

Висновки. Таким чином, здійснивши огляд матеріалів Архіву, що висвітлюють внутрішню структурну побудову підрозділу, та проаналізувати особливості цієї побудови, можна зробити певні висновки щодо впливу 
даних особливостей на бойову ефективність підрозділу. Саме відмінності нерегламентованої структури батальйону від регламентованого документами МВС зумовлює відносно високий рівень бойової ефективності «Азову». Спеціалізація підрозділів всередині батальйону давала можливість профілювати певні колективи добровольців на виконання окремих задач (як-то розвідувально-диверсійна діяльність чи ударно-штурмова робота). Крім того, наявність власних штабних структур і тим більше наявність батальйонного ЦБУ давала можливість на порядок більш ефективно керувати підрозділом як у процесі безпосереднього ведення бойових дій, так і у перервах між ними. Наявність власної системи рекрутингу давала можливість залучати необхідні кадрові ресурси, а наявність батальйонної інформаційної структури давала можливість додатково використовувати для батальйонних потреб інформаційні ресурси.

Специфіка внутрішньої структурної побудови батальйону є похідною від добатальйонного періоду фор- мування колективу, що згодом склав основу підрозділу. Саме від націоналістичних традицій того первісного колективу, що згодом став кадровим базисом «Азову», підрозділи отримували нетипові для армійської чи міліцейської структури назви. А націоналістична ідеологічна позиція цієї ж кадрової основи зумовила вкрай високий рівень мотивації особового складу. Тож, особливості й динамічний розвиток структури зумовлені не тільки зовнішніми обставинами, але й високо мотивованим та ініціативним особовим складом, який суттєво відрізнявся за віком, досвідом і мотивами від військовослужбовців строкової служби.

Зміни структурної побудови відображають етапи батальйонної історії та зумовлені процесом поступового перетворення підрозділу з партизанського загону у високопрофесійне регулярне збройне формування, яке згодом стало окремим загоном спеціального призначення «Азов» Національної Гвардії України (таку назву сьогодні носить підрозділ-нащадок однойменного батальйону).

\section{СПИСОК ВИКОРИСТАНИХ ДЖЕРЕЛ І ЛІТЕРАТУРИ}

«Азов». (2020). Азовська документація батальйонних часів прийнята до Центрального Держархіву громадських об’єднань. Офіційний сайт ОЗСП «Азов», 6 жовтня 2020 року. URL: https://azov.org.ua/azovska-dokymentacia-prujniata-do-cdago/ [дата зверн.: 26.06.2021].

Бутусов, Ю. (2014). Добровольчі батальйони: структура, страхи, проблеми бойового застосування. Дзеркало тижня, 29 серпня 2014 року. URL: https://zn.ua/ukr/internal/dobrovolchibatalyoni-struktura-strahi-problemi-boyovogo-zastosuvannya-_.html [дата зверн.: 26.06.2021]. 
Гладка, К., Громаков, Д. \& Миронова, В. (упоряд.) та ін. (2017). Добробати. Харків: Фоліо, 325 с.

Гуральська, А. (2015). Звіт: Добровольчі батальйони. Виникнення, діяльність, суперечності. Фундація «Відкритий Діалог», 18 травня 2015 року. URL: http://ua.odfoundation. eu/a/6444,zvit-dobrovolchi-batalyoni-viniknennya-diyalnist-superechnosti [дата зверн.: 26.06.2021].

Кравченко, М. (упоряд.). (2018). Визволення Маріуполя. Фотозбірка військової мемуаристики. Київ: Орієнтир, 132 с.

Стасюк, Ю. М. (2018). Українські добровольчі формування: створення та функиіонування (2014-2015 рр.): дис. ... канд. іст. наук: 07.00.01 — Історія України. Київ, 281 с.

Хомеріккі, М. (упоряд.). (2016). Широкинська операџія. Спогади учасників наступу. Київ-Маріуполь-Мена: Домінант, 72 с.

\section{REFERENCES}

“Azov". (2020). Azovska dokumentaciya batalyonnyh chasiv pryjniata do Centralnoho Derzharkhivu hromadskyh obyednan [The Azov documentation of battalion times was accepted by the Central State Archive of Public Associations]. URL: https://azov.org.ua/azovska-dokymentaciaprujniata-do-cdago/ [Accessed: 26.06.2021]. [in Ukrainian].

Butusov, Yu. (2014). Dobrovolchi bataliony: struktura, strakhy, problemy boyovoho zastosuvannya [Volunteer battalions: structure, fears, problems of combat use]. URL: https://zn.ua/ ukr/internal/dobrovolchi-batalyoni-struktura-strahi-problemi-boyovogo-zastosuvannya-_.html [Accessed: 26.06.2021]. [in Ukrainian].

Hladka, K., Gromakov, D. \& Myronova, V. (comps.) etc. (2017). Dobrobaty [Volunteer Battalions]. Kharkiv: Folio, 325 s. [in Ukrainian].

Huralska, A. (2015). Zvit: Dobrovolchi bataliony. Vynyknennya, diyalnist, superechnosti [Report: Volunteer Battalions. Occurrence, activity, contradictions]. URL: http://ua.odfoundation. eu/a/6444,zvit-dobrovolchi-batalyoni-viniknennya-diyalnist-superechnosti

[Accessed: 26.06.2021]. [in Ukrainian].

Kravchenko, M. (comps.). (2018). Vyzvolennya Mariupolya. Fotozbirka viyskovoyi memuarystyky [Liberation of Mariupol. Photo collection of military memoirs]. Kyiv: Orientyr, 132 s. [in Ukrainian].

Stasyuk, Yu. M. (2018). Ukrayinski dobrovolchi formuvannya: stvorennya ta funkcionuvannya (2014-2015 rr.): [Ukrainian Volunteer Units: creation and functioning (2014-2015)]. (Candidate's thesis). Kyiv, $281 \mathrm{~s}$. [in Ukrainian].

Khomerikki, M. (comps.). (2016). Shyrokynska operatsiia. Spohady uchasnykiv nastupu [Shyrokyne operation. Memories of the participants of the offensive]. Kyiv-Mariupol-Mena: Dominant, 72 s. [in Ukrainian]. 


\title{
Mykola Kravchenko
}

Philosophy Doctor in History (Ph. D.),

Doctoral Student,

M. S. Hrushevsky Institute of Ukrainian

Archeography and Source Studies, National

Academy of Sciences of Ukraine (Kyiv, Ukraine)

ORCID: https://orcid.org/0000-0003-1908-1595

\section{FEATURES OF THE STRUCTURAL CONSTRUCTION OF THE VOLUNTARY BATTALION “AZOV” IN MAY-SEPTEMBER 2014 ON THE MATERIALS OF ARCHIVE OF UNREGULATED BATTALION DOCUMENTATION}

\begin{abstract}
The article examines the processes of formation of the internal structure of the volunteer battalion "Azov", reflected in the materials of the archive of unregulated documentation of the Azov Volunteer Battalion for May-September 2014, recently recorded in the Central state archive of public associations. The aim of the publication is definition of the internal organization structure of the battalion "Azov", the process of its formation, correction and features. The research methodology involves the application of the principles of historicism, the usage of studying whole historical sources and being objective. Descriptive method, methods of classification and systematization as well as methods of analysis and synthesis have been used. The scientific novelty is conditioned by the high source value of the materials of the Azov Battalion Archive, which are currently completely unexplored within the framework of academic science; these materials are introduced into scientific circulation for the first time. The prospect of further research is that through the study of the internal structure of the battalion, it is possible to investigate the reasons for the high (compared to other volunteer formations) efficiency of the unit. The conclusions of the study are to determine the derivative nature of the specifics of the internal organization structure of the battalion from the pre-battalion period of team formation, which later formed the basis of the unit. In addition, it was noted that structural changes reflect the stages of the battalion's history and are due to the process of gradual transformation of the unit from a guerrilla unit to a highly professional regular armed formation, which later became a separate special unit "Azov" of the National Guard of Ukraine.
\end{abstract}

Keywords: volunteer movement, Ukrainian dobrobats, unregulated documentation, Anti-Terrorist Operation, Azov battalion. 